\title{
An imperial laboratory: the investigation and treatment of treponematoses in occupied Haiti, 1915-1934
}

\section{Um laboratório imperial: investigação e tratamento da treponematose no Haiti ocupado, 1915-1934}

Antony Dalziel McNeil Stewart

PhD Candidat, Newcastle University. School of History, Classics and Archaeology/Newcastle University. NE1 7RU - Newcastle-upon-Tyne - Reino Unido a.d.stewart2@ncl.ac.uk

Received for publication in January 2017.

Approved for publication in June 2017.

http://dx.doi.org/10.1590/S0104-59702017000500013
STEWART, Antony Dalziel McNeil. An imperial laboratory: the investigation and treatment of treponematoses in occupied Haiti, 1915-1934. História, Ciências, Saúde - Manguinhos, Rio de Janeiro, v.24, n.4, out.-dez. 2017, p.1089-1106.

\section{Abstract}

This article examines antitreponematoses work as part of US occupation public health policy in Haiti, a unique event in the history of international health. Yaws was highly prevalent in Haiti, but occupation doctors initially ignored it because of its close association with syphilis and stigmas attached to sexually transmitted disease. This changed when C.S. Butler asserted that yaws was "innocent" and that the two diseases should therefore be considered as one. Treatment increased as an anti-treponematoses campaign was now believed to hold great benefits for the occupation's paternalist and strategic aims, even though it ultimately failed. This work reflected Haiti's status as a public health "laboratory" which affected Haitian medicine for years to come and significantly influenced future campaigns aimed at disease eradication.

Keywords: Haiti; United States; yaws; syphilis; medicine.

\section{Resumo}

Este artigo investiga o trabalho antitreponêmico como parte da política norteamericana de saúde pública na ocupação do Haiti, evento inédito na história da saúde internacional. Era alta a incidência da bouba no Haiti, mas médicos da ocupação a ignoravam por ser parecida com a sífilis e pelos estigmas da doença sexualmente transmitida. A situação mudou quando C.S. Butler afirmou que a bouba era "inocente" e que as duas doenças deveriam ser consideradas uma. Surgiram mais tratamentos com uma campanha anti-treponêmica que trazia benefícios aos objetivos paternalistas e estratégicos da ocupação, apesar do seu fracasso final. Esse trabalho ilustra o Haiti como "laboratório" de saúde pública, o que afetou a medicina haitiana por anos e influenciou campanhas futuras para erradicar a doença.

Palavras-chave: Haiti; Estados Unidos; bouba; sífilis; medicina. 
The yaws work stands out as the most glowing chapter of all Haitian medicine. This is not only because of its tremendous accomplishments for the human and economic betterment of Haiti. It has contributed something else that reaches far beyond the confines of the little republic. A great number of scientific observations on the many aspects of the yaws question have been made during this work. These observations have gone into the medical literature of America and France and have been abstracted by the medical press of every country (Parsons, 1930, p.157).

In Dr. Robert Parsons' History of Haitian medicine, the anti-treponematoses campaigns took centre stage in a text issued solely to bask in the achievements of US imperial medicine in Haiti. The investigation and treatment of yaws and syphilis was heralded as one of the great triumphs of the US occupation of Haiti, which lasted from 1915 to 1934. Indeed, the successes of occupation medicine were often highlighted by even the most sceptical observers, such as Cameron Forbes (1930, p.1), who praised the "rate of progress" witnessed in Haitian public health during the years of military rule. However, the medical achievements of the efforts to combat treponematoses were modest, and by 1934, Haiti still faced a myriad of health problems; yaws and syphilis continued to be a major concern, as did tuberculosis, malaria and intestinal parasites. Instead, the development and execution of an anti-treponematoses campaign, and its subsequent remembrance as "the most glowing chapter of all Haitian medicine", originated from its importance in preserving and justifying a military occupation based on the longstanding, racialised notion that Haitians were incapable of managing their own affairs, and were arrested in their development by toxic cultural practices and chronic political instability.

This paper examines in detail the investigation and treatment of yaws and syphilis in occupied Haiti, seeking to understand the origins, implementation, and influence of these activities on occupation policy, Haitian society, and future international health work, "far beyond the confines" of 1920s Haiti. This work forms a unique example in this era of international health and imperial medicine, designed to correspond to the opinion that Haiti was emblematic of black independence, and in the white supremacist gaze, a perfect storm of socioeconomic crisis. Although medicine played a significant role in other contemporary US occupations, the cultural specifics of occupying Haiti - the first modern black republic, regarded by foreigners as an "American Africa" - lent greater significance to the military context of the medical work and the attitude of policy makers toward Haitian culture (Renda, 2001, p.47). Likewise, the way human treponematoses manifested in 1920s Haiti gave the work a unique bent as a result of the striking visible disfigurements of yaws and tertiary syphilis, the association of syphilis with sexual activity, the racialised, gendered interpretation of how this disease was contracted in Haiti, and its treatment using chemotherapeutic injections of arsenic-bismuth. These factors not only led to an extreme example of military medicine, which lays bare the imperial and white supremacist genes of international health, but also saw the implementation of a laboratorial attitude toward occupation medicine which greatly affected the lives of Haitian patients, decisively shaped the progression of Haitian public health over the coming years, and further fostered a culture of eradicationism in international health, serving as an important and under-examined precursor to Dr. Paul Soper's famous and (mostly) successful Haitian yaws eradication campaign of 1950-1952. 


\section{Public health and US occupation}

The US invaded Haiti on 28 July 1915, following the public assassination of the Haitian president Vilbrun Guillame Sam. That evening, Admiral William B. Caperton ordered five companies of US Marines and Navy bluejackets onshore to secure Port-au-Prince, after the diplomatic immunity of the French legation had been compromised. Over the following months, Caperton extended US control of Haiti, capturing the major port towns and seizing the customs houses, whilst in the capital the invaders appointed Philippe Sudré Dartiguenave as puppet president and dismissed the Haitian legislature. In rural Haiti, Marines were met with significant resistance from guerrilla forces known as Cacos, who were initially defeated in 1916 but rose up again a year later after the occupiers resurrected an old Haitian policy of kovè labour (forced work) for public works projects. Led primarily by Charlemagne Péralte and Benoit Batraville, the Caco resistance stifled the invaders until they were finally defeated in 1921 (Renda, 2001, p.10-11; Ramsey, 2011, p.118-121). Having at last secured the country, the US appointed John C. Russell as High Commissioner and proceeded to dominate all aspects of Haitian socioeconomic policy until 1929, when a student protest developed into a general strike and spelled the beginning of the end for American military rule (Nicholls, 1996, p.148-152). The occupation then gradually removed itself from Haiti in the early 1930s, and the last of the Marines left on 21 August 1934 (Renda, 2001, p.30-31).

Historians of the occupation generally agree that the decision to subject Haiti to military rule was driven by a combination of US strategic, paternalist and economic concerns. Hans Schmidt (1971, p.52-60) argues that Haiti's proximity to exiting US interests in the Panama Canal Zone and Guantanamo Bay made it a site of great strategic importance, and that invading Haiti to maintain stability (and remove German influence) was an act of policing the Caribbean which was consistent with the terms of the Monroe Doctrine. Brenda Gayle Plummer (1992, p.83-84) agrees, relating the invasion at its policies of economic extraction to President Taft's "Dollar Diplomacy", which aimed to ensure regional stability through increasing US economic interests in the Caribbean. However, she also notes the existence of an undercurrent of "determined moralism" and Jim Crow-inspired paternalism beneath US military rule (p.106-108). Mary Renda's Taking Haiti extends this idea, emphasising that the ethos of the Progressive Era and the racial politics of the American South not only shaped occupation policy but were instead its very lifeblood, and that a paternalist condescension toward Haitian culture and society influenced all aspects of US economic and geopolitical strategy (Renda, 2001, p.22-24).

However, what these histories do not acknowledge is how Haiti's health and sanitary conditions prior to 1915 greatly affected US attitudes toward the country. In the early twentieth century, Haiti was faced with a myriad of medical challenges including malaria, tuberculosis, yaws, syphilis, and intestinal parasites. The country was served by a limited medical corps, located mostly in private clinics in Port-au-Prince, but many doctors were attempting to harness the benefits of the microbiological revolution and expand scientific medicine beyond the capital (Bordes, 1992, p.25-26; 1980, p.47). Nevertheless, foreign observers fixated on disease and unsanitary practices, as part of their use of Haiti as what J. Michael Dash (1997, p.1) has termed an "inexhaustible symbol" to deride the prospect of black independence. 
For example, Spenser St. John's influential lambasting of Haitian society, Hayti, or the Black Republic, described the country as a "receptacle of every species of filth", whose capital was "the most foul-smelling, dirty and consequently fever-stricken city in the world" (St. John, 1888, p.X-XI), blaming such conditions on the failure of black independence. St. John and other writers, however, deemed the situation irredeemable, for Haiti's poor health rendered it the proverbial "white man's grave". Occupying Haiti became increasingly attractive for the US, not only because Haiti was increasingly being incorporated into the American "backyard", but also because advances in microbiology and the advent of what came to be known as tropical medicine opened up the possibility of long-term intervention (Sutter, 2007, p.724; Arnold, 1996, p.1-13). Indeed, as Espinosa (2009, p.1-8) notes in her study of yellow fever during the first US occupation of Cuba (1898-1902), these two factors were entwined.

During the occupation, policies for Haitian socioeconomic development were seen as crucial to the establishment and maintenance of military rule, and necessary to fulfil the paternalist and economic aims of the US in Haiti (Nicholls, 1996, p.146-148). Catalysed by the optimism of the burgeoning international health movement and the triumphalist narratives of "taming the tropics" arising out of the completion of the Panama Canal, as well as successful occupations of Cuba, the Philippines, and Puerto Rico, medicine became regarded by policy makers as an ideal tool for achieving the tasks at hand (Anderson, 2006, p.4-10; Briggs, 2002, p.16-17; Espinosa, 2009, p.1-8; Palmer, 2010, p.23-25; Sutter, 2007, p.725). In 1926, Commissioner Elwood Mead (13 Sep. 1926) declared that "the removal of pain, the lengthening of life and the increase in strength and ability" would enable Haitians "to perform the tasks necessary to the development and upbuilding of the country". Mead hoped that medicine would aid the Haitian economy to the benefit of US interests in Haiti, as well as demonstrate to sceptical onlookers in both Haiti and the United States that military rule was justified.

However, as Alison Bashford (2007, p.2-7) has explained, international health not only crossed borders, but redefined boundaries and divisions in numerous ways as it developed public health systems. Health policy in occupied Haiti would serve not only to justify the creation of an imperial dominance over Haitians, but would provide another opportunity to show the world the superiority of American medical methods (Cueto, 1994, p.3). Officials believed that campaigns to improve Haitian public health represented "very good propaganda" for the occupation, especially after its early years were marred by consistent reports of Marine brutality, which had led to a Senate investigation into the atrocities (Stitt, 1930, p.XVII). Additionally, as David McBride's all-too-brief consideration of science and technology in occupied Haiti pertinently alludes, public health also served as an important tool to "control the microworld of the Haitian peasant", a weapon deployed to break the control of the socalled "charlatan" Vodou priests and dokte fe (herb doctors) in the Haitian hinterland, and was also an ally for military efforts to secure control in regions rife with guerrilla resistance during the Caco Wars (McBride, 2002, p.84). Consequently, US medical personnel were sent "out into the bush and up on the mountainside", ostensibly to "awaken the medical and hygienic conscience of the people", and in the cities they supplanted the Haitian medical corps in training and administration, for the old guard and the French methods were simultaneously viewed as an archaic brake on Haitian progress and as a threat and an 
alternative locus of power that might dare question the hegemony of the Marine bayonet (Butler, Peterson, 5 Oct. 1926).

In the early twentieth century, a powerful association was forged in foreign minds between dirt, disease, and the alleged failures of the Haitian medical corps, which was used to declare that Haiti - this great project of black independence - had failed. Occupation medicine was thus deployed to "uplift" Haitians from their alleged self-imposed squalor, whilst proving that Haitians were not capable of doing this themselves. It was upon this tension that occupation public health policy was planned, executed, and judged, and it also shaped the legacy and consequences of the anti-treponematoses campaigns and lent the project its historical significance.

\section{The opportunity of yaws, the problem of syphilis}

In the 1910s, yaws was a major health issue in Haiti, alongside malaria, tuberculosis, and intestinal parasites. Ary Bordes (1992, p.34-35), the great chronicler of Haiti's medical history, wrote that at that time, yaws was the "master" of the countryside who "reigned unhappily" over the lives of the peasantry. During the early days of the occupation, Admiral Caperton tasked doctors H.A. May and P.E. Garrison with reporting the medical and sanitary conditions in Port-au-Prince to him, and the surveyors observed that "there were many people going about the streets with such open lesions of disease upon their bodies as to make them a menace and a source of infection to others", noting symptoms that likely indicated yaws (May, Garrison, 1 Oct. 1915, p.11).

A targeted anti-yaws campaign represented a golden opportunity for Haiti's occupiers to deploy medicine that served the aims of military rule. Yaws is a bacterial disease, and along with syphilis, bejel, and pinta is part of a family of diseases known as the human treponematoses (WHO, undated). It is contracted through human contact, entering the body through an existing lesion or injury to the skin barrier, and is most common in children under 15 years of age. Yaws principally manifests itself through infections of the bone and its striking skin lesions (Rinaldi, 2012; Čejková et al., 2012). Today yaws is on the decline and is seen as a "low hanging fruit" for total eradication, since it is easily treated by penicillin injections or recently, a single dose of azithromycin (Rinaldi, 2012). Yet in the early twentieth century, well before such treatments were available, curing yaws was seen as a relatively straightforward task through the use of arsenic therapy, developed by Paul Ehrlich in 1912 (Perine et al., 1984 , p.3). For occupation administrators, who had limited funds and were unwilling to engage in intensive treatment or prevention campaigns due to their scepticism of Haitian ability, an easily implemented top-down treatment campaign was an ideal way to speedily improve Haitian public health. Furthermore, the visually arresting and disturbing tertiary symptoms of yaws offered a captivating propaganda opportunity. As with Chagas disease in 1920s Brazil, the disfiguring effects yaws caused on the body ensured increased attention for this disease from concerned parties over other diseases which were "less visible" or more difficult to treat, such as the more prevalent and deadly tuberculosis (Stepan, 2001, p.194196; McBride, 2002, p.96.) The visual narrative of removing the cruel lesions of yaws would appear almost miraculous to the untrained onlooker. 
Yaws treatment would additionally benefit Haiti economically by preventing lifelong disability. Rockefeller Foundation (RF) surveyor George C. Payne, who worked closely with the occupation public health organisation Service d'Hygiène Publique (SHP, established in 1919), argued that it was not the "crippling lesions" of end-stage yaws that most damaged Haitian society, but rather that the problem lay in the very much larger numbers of cases of disability which impedes the worker but does not prevent him engaging in some sort of occupation. Payne suggested that cases of chronic yaws were harming Haitian agricultural productivity, and that those affected by yaws in early life were especially vulnerable. Infected children, wrote Payne, were "more than likely doomed to a lifetime of suffering from ulcers, 'crabes', crippling contactures, bone and cisceral lesions and less frequently 'nervous lesions'” (Payne, 20 Jan. 1926, p.12). Tackling yaws would help improve agricultural productivity in the long run by preventing disability in tomorrow's farm labourers, potentially benefiting the American-owned plantations established during the occupation as well as customs revenue, which at that time was overwhelmingly derived from agricultural exports and crucial for funding military rule (Trouillot, 1990, p.103). Payne also hoped that a single disease campaign - yaws being the obvious choice - would help fuel the evangelism of US scientific medicine in rural Haiti, and would help warm the resistant rural residents to the Marine interlopers, declaring that "the great mass of the rural population are utterly ignorant and indifferent to the service of modern medicine and will remain so until it is carried to them in their villages and homes in the form of relief from some prevalent and easily recognisable disease" (Payne, 20 Jan. 1926, p.12).

Yet in the early years of the occupation, the possibility of pursuing an anti-yaws campaign was remote. Indeed, doctors and medical administrators did not pay significant attention to the disease until 1923. This was because (at least initially) the symptoms and sufferers of yaws were frequently misdiagnosed or associated with leprosy or syphilis. Prior to 1915, both Haitian and foreign observers remarked upon what they perceived to be a severe problem with leprosy in rural Haiti. In 1898, the Haitian medical student Victor Boyer (20 June 1898, p.43) remarked that the prevalence of leprosy was such that Haiti now warranted the title of "a leper country", whilst in 1910 the British explorer Harry Johnston (1910, p.195) wrote that "leprosy has obtained a considerable hold over certain districts, especially in the plains, and syphilis is still answerable for terrible ravages among the coast and town population". In 1915, May and Garrison reported to Caperton that the two most prevalent diseases in Port-au-Prince were "syphilis and leprosy" and that the former was "very prevalent" and one of "the most urgent matters" in Haiti at the time (May, Garrison, 1 Oct. 1915, p.10-11). In these observations, it is likely that the tertiary symptoms of the two treponematoses were misidentified as indicative of leprosy, especially considering that mentions of leprosy in occupation medical records became increasingly rare after these two observations, and little action was taken by the SHP to control it (Bordes, 1992, p.273). At this early stage, health administrators were also not willing to engage with leprosy. In 1915, there was no known remedy for this illness, and public health officials preferred to isolate patients to control its spread. It was not until the 1920s that medical professionals began to envisage the possibility of a "cure" for leprosy, and it was only in the 1940s that an effective treatment, dapsone, 
became available (Kakar, 1996, p.224-226). In 1915, leprosy management offered little reward for those wishing to pursue public health policy as an aid to military rule and its desires.

The initial identification of yaws symptoms with leprosy quickly subsided, but the association between yaws and its cousin syphilis endured, arresting hopes of an antiyaws campaign for many years. Recent research has shown that yaws and syphilis share approximately $99.8 \%$ of their genetic code, and since 1984 they have been regarded not as separate species of Treponema bacteria but instead as two subspecies of Treponema pallidum; subspecies pertenue for yaws, and subspecies pallidum for syphilis (Čejková et al., 2012). Many occupation personnel, including medical staff, were unfamiliar with yaws and its symptoms; considering the similarity between many of the tertiary symptoms of yaws and syphilis (including congenital syphilis, which is passed on to children during pregnancy), it is understandable that US observers frequently interpreted the manifestations of yaws as those of its notorious relative (Center for Disease Control and Prevention, 2016). Furthermore, contemporary laboratory diagnosis could not distinguish between the two diseases. Bordes notes that Dr. F. X. Koltes, when conducting Wasserman tests on Haitian gendarmes, prisoners, and schoolboys, discovered that $74 \%$ of the sample were infected with Treponema. All cases were subsequently diagnosed as syphilis (Bordes, 1992, p.179). In 1922, High Commissioner John C. Russell (14 Apr. 1922, p.2) made a similar observation, reporting to the RF that "70$80 \%$ of the population are syphilitic".

Unlike yaws, syphilis is transmitted primarily through sexual contact, or is contracted congenitally. The assumed high prevalence of syphilis was quickly connected to derisive, longstanding stereotypes of uncontrolled black promiscuity and decades of polygenist criticism of the uncleanliness and debauchery of Haitian women (Renda, 2001, p.55). Spenser St. John (1888, p.155-156) dedicated many lurid pages to such commentary, claiming that "continence is not considered a virtue" in Haiti, and "no effort is made to keep the minds or bodies of the young girls chaste". "Their greatest defect", however, was supposedly "their want of cleanliness" (St. John, 1888, p.175). St. John charged that failings in Haitian motherhood and hygiene infected Haitian society through "indiscriminate" sexual promiscuity, to an extent that even presidents were felled by its consequences. For example, President Riche was said to have succumbed "at an advanced age from the effects of debauchery", as did the Vodou priests, whose alleged decadence saw them perish "covered with leprosy and incurable sores" (St. John, 1888, p.92, 227-228). Such assessments informed later US observations of Haitian health. In 1921, the military intelligence officer R. Shepard reported from Aux Cayes that "there is disease of all kinds" and that "syphilis and gonorrhoea is very common". This he attributed to "promiscuous and worse than beastly intercourse", noting also that "syphilis manifests itself in all its stages" (Shepard, 2 Dec. 1921).

This racialised, gendered derision of Haitian culture for decades had informed the notion that Haiti's public health difficulties were of its own making, and such opinions consequently had long discouraged medical interventions and continued to do so even after military rule had begun. Caperton's chief of staff, Edward Beach, was not alone in his belief that Haiti was a potential paradise, a "beautiful country [with] fertile soil and a gentle climate" made torrid by its inhabitants. He believed "the fault is with Haiti" (Beach, 17 June 1916; 3 June 1916, p.16). As a result, during the early years of the occupation, US medical personnel 
had little interest in tackling a public health issue which, even though its alleviation would benefit the aims of military rule, they believed was caused by insurmountable biological and cultural defects among Haitian society. Additionally, those who wished to take on syphilis, such as High Commissioner Russell, received little assistance for the same reasons. In 1922, Russell appealed to the RF for help with an anti-syphilis campaign, but the RF preferred to steer clear of a campaign that might require intensive medical education work (Palmer, 2010, p.67). In response, RF official Wickliffe Rose (17 May 1922, p.2) simply declared that the RF "do not engage in the control of venereal disease". As a result, in the early years, occupation policy toward the human treponematoses focused only on prevention: namely, keeping the Marines away from the bordellos (Bordes, 1992, p.178-179).

\section{"Innocent syphilis"}

Those who wished to tackle yaws and syphilis in Haiti therefore had to engage with the racist scepticism attached to tackling sexually transmitted disease in black societies, and also needed to assert the utility of such a campaign for the aims and purposes of the occupation. In the early 1920s, attitudes among medical staff shifted with regard to the causes and prevalence of yaws and syphilis, which, alongside other important changes in the character of the occupation, led to the inauguration of a grand anti-treponematoses campaign. In the early 1920s, guerrilla resistance in the Haitian hinterland was finally extinguished, following a brutal campaign of Marine suppression. SHP doctors were therefore able to move into areas which had previously destabilised by conflict; Bordes notes that soon afterwards the Haitian doctor R. Charmant and the Navy physician Paul Wilson separately observed and recorded the high rural prevalence of yaws (distinct from syphilis), and both called for the SHP to extend their work into the countryside to tackle this menace (Bordes, 1992, p.181).

However, the appointment of Dr. Charles S. Butler catalysed a decisive change in occupation attitudes and policies toward the human treponematoses. Whilst he was stationed in the Philippines during the US of this country, Butler began to develop the idea that yaws and syphilis should be considered a single illness called "treponematosis", and when he arrived in Haiti he worked to incorporate this theory into SHP policy (Parsons, 1930, p.161-162). In practical terms, Butler's theory played heavily on the association between the symptoms of yaws and its better-recognised cousin syphilis. He demanded that the occupation take action on treponematosis, claiming that its ravages were felt by over $70 \%$ of Haiti's population. But knowing the stigma attached to sexually transmitted disease, Butler contended that "much of this syphilis was innocent". By arguing that yaws and syphilis were variations of the same disease, and differ only (and significantly) in the manner in which they are contracted, Butler subtly suggested that syphilis could be contracted through other, non-sexual or congenital means. In doing so, Butler attempted to undermine the notion that the high prevalence of human treponematoses in Haiti was the result of black sexual promiscuity, whilst implicitly accepting the latter notion as fact. Butler did not challenge the hegemonic belief that black sexual practice was uncontrollable, rather that "in this instance" it was not a roadblock to medical progress (Butler, 1926, p.7-9). 
Butler's efforts to change attitudes toward yaws and syphilis were aided by George Payne. Payne was sent to Haiti in 1924 by the RF's International Health Commission (IHC) to survey the health conditions in the country and to determine the utility of any future RF public health interventions there to control the prevalence of hookworm (Howard, 20 Jun. 1924, p.1-3). In order to curry favour with locals who were wary of the presence of the RF doctor and his unknown intentions, Payne offered free consultations and treatment for all diseases when he surveyed an area for intestinal parasites. Following the example of earlier IHC Caribbean work, Payne's team was comprised mostly of Haitian staff, including the promising medical student Camille Lherisson, and they communicated with their patients using Kreyol Ayisyen and local terminology for yaws and syphilis to translate their purposes to the patients. After over a year of this intensive engagement with rural Haitian communities, Payne arrived at the conclusion that Haiti's primary health concern was "treponematosis", not hookworm, and told the RF that they would better serve Haitian public health by contributing the institution's resources toward tackling yaws and syphilis (Payne, 20 Jan. 1926, p.9). Like Butler, Payne framed this assertion around the idea of "innocence", and with the authority of a scientist Payne declared that "the differentiation of their causative organisms is not universally accepted", and in practical public health work it instead led only to "endless confusion" and "served no useful purpose". He took care to explain to the RF heads that "in rural Haiti, treponematosis has no relation to venereal disease", pointing to its prevalence among children (who likely suffered from yaws or congenital syphilis) to make his case (Payne, 4 Feb. 1926, p.1).

Payne also believed that an effective anti-treponematoses campaign would prove the effectiveness of US medicine and culture, serving the aims of both the RF and the US occupation as a whole - an opinion he garnered from his experiences in the field. Despite their efforts to ingratiate themselves with the locals, in certain areas Payne and his team were met with great resistance, which the US staff attributed to Haitian culture and ignorance. W.A. Hoffman, the Payne survey's resident entomologist, lamented the difficulties they faced, speculating that these arose from "the objection of the people to strangers entering their homes for a purpose they could not understand" (Hoffman, 15 Jan. 1926, p.6). Payne himself increasingly viewed Vodouism as the main culprit, likely based on his years of experience with spiritual resistance during other RF efforts such as the 1918 Trinidad campaign (Palmer, 2010, p.174-175). Payne believed he had difficulties collecting a sufficient number of stool samples because "the people were not familiar with the practices of modern medicine, and the giving of faeces was associated in their minds with superstitious practices of charlatans who pretended to work charms by the possession of such specimens" (Payne, 20 Jan. 1926, p.7). Hector H. Howard (20 Sep. 1926), who in charge of the RF's Caribbean affairs, held a similar view, believing that the sway of "charlatans" was strengthened by the Haitian medical corps' failure to establish a presence in rural areas, declaring that it was "not strange that a greater part of the people prefer to take their chances with the Voodoo priests, rather than patronize the local medical man". Payne and Howard therefore hoped that a campaign against yaws and syphilis would have an evangelising effect on rural Haitians through, as Payne wrote, "a striking demonstration of the superiority of modern medicine over the methods of the local charlatan, be he voodoo priest, herb doctor, or former hospital aide of the Haitian Army". 
He regarded this as a crucial preliminary step which would precede further public health reform in the countryside, arguing that "until the rural Haitian has acquired such confidence that he will seek the physician's opinion in serious cases as well as in minor ones, little can be done by the physician in education along preventative lines" (Payne, 4 Feb. 1926, p.2).

As a result of these efforts by Payne and Butler, the SHP began a treponematoses treatment programme, which was assisted by a boost in funds in both 1922 and 1923, since now funds could be redirected from military action to public health (Butler, 1926, p.5-9). In the newlycreated rural dispensaries, the SHP began administering neo-salvarsan (organoarsenic) and bismuth injections to those who visited the clinics, free of charge (Payne, 20 Jan. 1926, p.11). Encouraged by the social, economic, and strategic advantages this work promised, the SHP quickly expanded the programme. Between 1922 and 1928, the number of arsenic-bismuth doses administered by the SHP increased from 23,000 to 551,000 per annum (Bordes, 1992, p.178).

\section{Enter eradication}

Payne's request that the RF fund an anti-treponematoses campaign was declined. The foundation was more concerned about the lack of satisfactory medical infrastructure in Haiti. Howard (20 Sep. 1926, p.1) believed that "as long as the medical school remains as it is ... there seems but little hope for the future of either curative or preventative medicine in Haiti". Consequently, the RF bankrolled a revamp of the National School of Medicine in Port-au-Prince and constructed a new medical laboratory, in accordance with its belief that a reasonable public health infrastructure should be in place prior to the commencement of any large-scale disease control projects (Howard, 28 May 1926, p.1-2). However, as the 1920s wore on and US attitudes toward Haitian culture and society hardened, the SHP were drawn in the opposite direction. Occupation administrators frustrated by the lack of immediate progress on their reform projects quickly attributed these failures to the Haitians, their race, and their culture, rather than to any faults within the project design and execution. For example, Howard (10 Mar. 1925, p.1-2) blamed the Payne survey's sluggishness on the subordinate Haitian staff, whom he considered to have the lowest "intelligence and dependability" he had ever encountered in the West Indies, and he claimed that no work was being done at all without the direct supervision of Payne himself. Whilst Howard hoped this situation could be rectified through educational reform, many SHP administrators were more sceptical. C.S. Butler, in a report co-authored by his colleague E. Peterson, suggested that "it would take many years of evolutionary development before success was reached", reflecting the widely held belief that long-term infrastructural reform was too difficult to achieve (if not impossible) given the SHP's limited time and resources, because most occupation officials believed the Haitians to be almost insurmountably backward (Butler, Peterson, 5 Oct. 1926, p.7).

The idea of a disease eradication campaign thus became increasingly attractive to US medical personnel, and "treponematosis" became the ideal candidate because they had what they believed to be an effective treatment model, because and yaws and syphilis are only prevalent in humans. A successful eradication programme would therefore bypass any need to ensure long-term public health reform or to interact with Haitian cultural practices they 
deemed unalterable. As Stepan (2011, p.56) argues, Navy doctors also favoured eradication because the very concept of disease eradication originated from (and was entwined with) military logic, designed to wipe a pathological enemy from the map. In Haiti, this attitude had a direct predecessor in the Caco Wars, which had taken on an eradicationist tone as the gendarmes were moved into "infected" areas to obliterate the "infestation" of the guerrillas (Gendarmerie..., 15 Jul. 1921, p.7). Furthermore, complete eradication of the shocking, disfiguring diseases of yaws and syphilis would paint a powerful justification of US military rule, and of the resources already spent upon this now-prolonged occupation.

But despite the infusions of funding, the SHP were still operating with tight purse strings, and a treponematoses eradication campaign would consequently have to be conducted on the cheap. To solve this issue, in 1929 Paul Wilson designed a mobile dispensary campaign that became known as "the travelling yaws clinic" (Parsons, 1930, p.146). Wilson, who had previously called for a "war" on yaws, hoped to use his mobile clinic to "mop-up" areas of Haiti which were beyond the reach of the rural SHP dispensaries (Parsons, 1930, p.146-149). His plan was also wrapped up in social and cultural considerations. Many patients were wary of travelling to the rural dispensaries, since this often involved a lengthy and precarious journey, and they were also discouraged by the enduring suspicion of the occupiers and local stigmas attached to yaws (McBride, 2002, p.96). The travelling yaws clinic would instead go directly to the patients, and like the Payne survey would utilise its predominantly Haitian staff to save costs and increase trust in the mobile dispensary. Two physicians accompanied Wilson during this project: the American Maurice Mathis, and Camille Lherisson, a Haitian held in high regard by occupation administrators for his work with George Payne (Parsons, 1930, p.154).

Unfortunately, the travelling yaws clinic rolled out only in one district, Morne La Selle, before it was abandoned due to budgetary constraints (Bordes, 1992, p.179). This decision was likely connected to the events of 1929, when the American position in Haiti was placed in serious doubt following the Great Depression and a general strike in Haiti, sparked by student protests that fuelled simmering resentment toward military occupation. The lack of immediate success made Wilson's project vulnerable, which McBride blames on Wilson "overemphasising the massive dissemination of treatment for yaws but essentially ignoring the more difficult task of reducing social conditions linked to continuous, widespread new exposure to diseases like yaws" (McBride, 2002, p.97). This was certainly an issue, since arsenic-bismuth treatment is chemotherapeutic and consequently requires dozens of repeat doses to achieve results (Rinaldi, 2012; Perine et al., 1984, p.3; Jones, 1981, p.45-46). Repeat visits to patients, which were later identified as essential to a yaws eradication project, were very difficult to make when the mobile treatment model was used (Samane, 1956, p.906). Eradication of yaws also depended upon rapid treatment of all cases in Haitian society, since the disease can be contracted again even after it is cured. Wilson therefore would have had to have conducted regular, multiple appointments for every single yaws sufferer in Haiti for his campaign to have succeeded. McBride, however, suggests that such oversights are a fault within eradication campaigns in general, and as a result he fails to recognise that Wilson's very choice of an eradication campaign and his intentional ignorance of social conditions 
cannot be separated from the imperialist context in which the project was designed and executed (McBride, 2002, p.7). Wilson himself saw its purpose in the following manner:

The successful elimination of yaws from Haiti would greatly increase the confidence of the people and facilitate later educational work. [Additionally] Yaws is still a cause of great economic loss, and while it is believed that no small progress has been made, yet we will have it always with us unless it is eradicated from the more isolated districts and thus prevent contamination of districts that have already been cleaned. [...Finally] the yaws pandemic is the only public health problem which can be solved in a relatively short time (quoted in Parsons, 1930, p.149-150).

Wilson, when he introduced the policy in 1929, stated that such a project was necessary because of the economic, educational, and rhetorical benefits it would provide Haiti and its occupiers. He also clearly understood the need for total eradication, but framed it not only as a medical necessity but as a "cleaning" that must be conducted by the US "in a relatively short time", likely because he did not view Haitians capable of adopting the required social reforms to control the spread of yaws or capable of continuing an eradication project inaugurated by the occupiers. Wilson believed that the "principal reason" SHP medical policies, including the travelling yaws clinic, failed was because of "the ignorance of the people" (McBridge, 2002, p.97). Once again, in their own eyes the occupation medical officials could do no wrong, and any failures were set squarely at the feet of the Haitians. This is the essential contradiction within the occupation's medical paternalism; the Haitians were constantly perceived as being in dire need of outside assistance, but were simultaneously deemed incapable of properly receiving the benefits any help provided them, because they were overwhelmingly viewed by US officials as permanently arrested by their race and culture. This notion was encapsulated toward the end of military rule within a surge of occupation apologism, which trumpeted public health policies as evidence of the benevolence and worth of the entire intervention.

SHP Deputy Robert Parsons dedicated an entire text, The history of Haitian medicine (first published in 1929), to this endeavour. Within its triumphalist pages he lauded Wilson and his choice of a mobile treatment model, not as a necessary adaptation to local realities and strategic concerns, but instead as evidence of the doctor's remarkable ingenuity. Haitians, who made up the vast majority of the staff, were almost completely absent in Parson's depiction of the travelling yaws clinic, which he declared an outstanding and enduring success. Only Camille Lherisson earned a mention, and only so that his noteworthy ability could be attributed to his white American ancestor (Parsons, 1930, p.146-153). Efforts like Parsons' ensured that modest and ineffectual attempts to improve Haitian public health, such as Wilson's mobile clinic, became central aspects of the way the occupation was remembered and celebrated in the years to come, amplifying the intelligence and nobility of US doctors and marginalising the Haitians to a passive or disruptive role.

\section{Arsenic therapy in the prisons}

The use of public health policy to ensure a favourable legacy was not limited to literary efforts like the one produced by Parsons. A second, overlooked front in the anti-treponematoses 
campaign was established in the prisons, and during the occupation's final years efforts to treat yaws and syphilis served to bolster the long-term reputation of US military rule in Haiti. In the penitentiaries, doctors held sway over patients in a manner unmatched in the rest of Haiti. Patients had no choice whether or not to visit their local dispensary, since they were locked within it. As soon as they were incarcerated, prisoners were given a mandatory smallpox vaccination (Garde..., 1934, p.29). Those who were diagnosed with yaws and syphilis were treated using neo-salvarsan injections and doses of bisomol (bismuth). Table 1 collates statistics provided by the Garde d'Haiti (the military police who operated the prisons) for the final five years of the occupation, 1929-1934, during which a dramatic rise was seen in both the number of prisoners treated and drugs administered. This remarkable uptick in anti-treponematoses work came at a time when medical circles increasingly questioned the effectiveness of arsenic-bismuth therapy for treating the human treponematoses (McBride, 2002, p.98). Against a tide of the increasing "Haitianisation" of all government administration, the prison doctors intensified their treatment of yaws and syphilis patients. Such action at this time was therefore likely to have been part of a legacy management effort, aimed at highlighting the diligence and intensity of occupation public health work when subsequently contrasted with the expected deterioration in health care standards after Haiti's management was returned to Haitian officials. In this situation, overtreatment was a possibility, especially in light of the sentence repeated in each of the yearly reports, stating that "the [statistics] show the rather extensive medication given prisoners for syphilis and yaws. The large amount of drugs poured yearly into the prison population should have a most salutary effect upon the civil population of the country" (Garde..., 1934, p.29). An overdose of highly toxic neo-salvarsan was extremely dangerous, whilst each treatment required a painful intramuscular injection (Jones, 1981, p.45-46). Given that success was not guaranteed with arsenic therapy, and that reinfection with yaws or syphilis was certainly a possibility, the excessive administration of this treatment demonstrated reckless disregard for the health of the Haitian prisoners. But it was deemed necessary: necessary to make prisoners "clean" before they re-entered Haitian society, and necessary as part of the US strategy that emphasised efforts to combat treponematoses in order to cast the occupation in a more favourable light once the Marines had left, an effort quantified by the weight of numbers treated and the amount of arsenic "poured yearly" into Haitian bodies.

Table 1: Treponematoses treatments administered by Garde d'Haiti to prisoners nationwide

\begin{tabular}{l|l|l|l|l|l}
\cline { 2 - 6 } & $\begin{array}{l}1 \text { October 1929- } \\
1 \text { October 1930 }\end{array}$ & $\begin{array}{l}1 \text { October 1930 } \\
-1 \text { October 1931 }\end{array}$ & $\begin{array}{l}1 \text { October 1931 } \\
-1 \text { October 1932 }\end{array}$ & $\begin{array}{l}1 \text { October 1932 } \\
-1 \text { October 1933 }\end{array}$ & $\begin{array}{l}1 \text { October 1933 } \\
-31 \text { July 1934 }\end{array}$ \\
\hline $\begin{array}{l}\text { Neo-salvarsan } \\
\text { injections }\end{array}$ & 68 & 82 & 53 & 1260 & 1278 \\
\hline $\begin{array}{l}\text { Number of } \\
\text { prisoners } \\
\text { receiving } \\
\text { bisomol }\end{array}$ & 3145 & 3367 & 4369 & 5960 & 5800 \\
\hline $\begin{array}{l}\text { Number of } \\
\text { doses of } \\
\text { bisomol given }\end{array}$ & 9105 & 8789 & 11596 & 12860 & 11913 \\
\hline
\end{tabular}

(Source: Garde..., 1930, p.59; Garde..., 1931, p.55; Garde..., 1932, p.43; Garde..., 1933, p.41; Garde..., 1934, p.29) 


\section{The imperial laboratory}

The inauguration and development of the anti-treponematoses campaigns reflected how occupation medical officials increasingly saw Haiti as a "virgin field" and a "laboratory" for public health work and experimentation (Parsons, 1930, p.5). This type of attitude was no stranger to US imperial medicine (for example, see Briggs, 2002, on Puerto Rico), but the manner in which it appeared and operated in Haiti was triggered and shaped by Haiti's status as a place of emblematic black backwardness. The tremendous control the US wielded over Haiti was certainly a factor. "An extraordinary opportunity is now offered for Americans to study yaws in the Republic of Haiti", noted Dr. Howard Fox $(1929$, p.820) at the start of his published observations on yaws, for it was "a country which is close at hand and which is temporarily under the protection of the United States". Fox was not alone in this assessment, and Wilson and Butler's work on treponematoses was extended in a serious of publications, highlighting the medical discoveries made in occupied Haiti. Wilson and Mathis, presenting researched gathered during the travelling yaws clinic programme in the Journal of the American Medical Association (Mathis, Wilson, 1930), suggested the existence of an insect vector, the gnat Hippelates flavipes, in transmission of Treponema pallidum pertenue between bodies. Butler (1930), meanwhile, further developed his arguments supporting the similarity between yaws and syphilis in International Clinics. Their theses were subsequently exaggerated for effect by Parsons, who stated that these tentative works instead offered "conclusive proof". The scientific achievements of the SHP were placed on a lofty pedestal, alongside the modest achievements of the treponematoses treatment programmes. Outside of Haiti, Butler's assertions remained hotly debated, and his contemporary Thomas B. Turner $(1937$, p.504) instead argued that there were "easily recognisable differences between the two diseases" based upon research conducted in Jamaica and the US.

The (over-)emphasis of the scientific and medical significance of the occupation's treponematoses work fuelled the influence of its legacy, both in Haiti and beyond. Such arguments in turn were stoked by a derisive attitude toward Haitian culture, and set against the backdrop of the expected deterioration in health conditions post-1934. In 1928, Intelligence Officer Joseph L. Moody (Aug. 1928) claimed that "an unfortunate chain of cause and effect binds the [Haitian] Republic which will require united and sustained effort to destroy". Many involved in occupation health shared Moody's concerns, leading to their support of eradication campaigns; the very appeal of these campaigns lay in their potential to succeed without having to tackle the social and cultural factors which affected the prevalence of a disease (Stepan, 2011, p.70-75). Additionally, any public health achievement during the occupation was heralded as remarkable because of Haiti's enduring reputation as an emblematic socioeconomic disaster zone, a reputation which was enhanced by voices like Moody who blamed any failures on the Haitian race, culture and society. Consequently, the notion flourished that if medical achievements could be made in somewhere as difficult as Haiti - a place which, according to H.H. Howard (10 Mar. 1925, p.1), had problems "more formidable and numerous ... than would be met with elsewhere" - they could be replicated with phenomenal results in other, less challenging environments, or with improved technologies. An important and understated legacy of the anti-treponematoses campaigns was its significant contribution 
to the belief that it was possible to eradicate yaws from a society (Bordes, 1992, p.179), a legacy based heavily upon actions shaped by US attitudes toward Haitian culture and society. International health agents who were determined to eradicate yaws returned to Haiti in the 1940s, now armed with penicillin. They were drawn to Haiti by memories of Wilson's campaign, to the point where the Pan-American Health Organisation began their project by replicating Wilson's mobile treatment model (Samane, 1956, p.906). It later abandoned this model for a more effective house-to-house approach, and Dr. Paul Soper's campaign went on to prove incredibly successful, spearheading efforts to massively reduce the prevalence of yaws worldwide (Stepan, 2011, p.124-128; Cueto, Palmer, 2015, p.149-150).

The legacy of the anti-treponematoses work was greatest in Haiti itself. It was central to the SHP's encroachment into rural Haiti and its marginalisation of the old Haitian medical corps, which considerably disrupted the existing medical infrastructure of Haitian society. The SHP's decision to favour mass treatment and eradication programmes over any efforts toward long-term public health reform left this disruption unrectified by the time the Marines departed in August 1934. The extent to which Haitian public health declined (if at all) after the end of the occupation is a complicated question and will not be discussed in detail here, but it must be noted that, as a result of the occupation medical policy which was exemplified and influenced by the investigation and treatment of yaws and syphilis, Haitian medical personnel had been starved of experience for nearly two decades, and were tarnished by endless accusations of incompetence and inertia in the face of Haiti's public health challenges. This rendered Haiti more reliant on foreign medical assistance than ever before, and because of scepticism with regard to chances of success, this assistance continued to favour short-term, top-down interventions that further undermined efforts to stabilise the now Haitian-led SHP. Over the following decades, Haitian health care became increasingly subject to foreign involvement, and the legacies of this imperial laboratory continued to wield influence over Haitian society even after penicillin finally brought these diseases under control. Albeit for reasons far beyond his triumphalist viewpoint, Parsons was right that "the yaws work stands out", as the occupation's investigation and treatment of treponematoses was a unique and important event in the history of Haiti and international health.

\section{REFERENCES}

ANDERSON, Warwick.

Colonial pathologies: American tropical medicine, race and hygiene in the Philippines. Chapel Hill: Duke University Press. 2006.

ARNOLD, David.

Introduction: tropical medicine before Manson. In: Arnold, David. Warm climates and Western medicine, 1500-1900. Amsterdam: Rodopi. 1996.

BASHFORD, Alison.

The age of universal contagion: history, disease and globalization. In: Bashford, Alison. Medicine at the border: disease, globalization and security,
1850 to the present. Basingstoke: Palgrave Macmillan. 2007.

BEACH, Edward.

Letter to William B. Caperton. William Banks Caperton Papers. 1.1. (Manuscripts Division, Library of Congress). 17 June 1916.

BEACH, Edward.

Conditions in Haiti. William Banks Caperton Papers. 2.1. (Manuscripts Division, Library of Congress). 3 June 1916.

BORDES, Ary.

Haiti médicine et santé publique: période de 
l'occupation américaine, 1915-1934. Port-auPrince: Imprimerie Deschamps. 1992.

BORDES, Ary. Evolution des sciences de la santé et de l'hygiène publique en Haïti: fin de la période colonial 1915. Port-au-Prince: Imprimerie Deschamps. 1980.

BOYER, Victor.

Le lepre en Haiti. Les Journal des Etudiants. v.10, p.42-46. 20 June 1898.

BRIGGS, Laura.

Reproducing Empire: race, sex, science and U.S. imperialism in Puerto Rico. London: University of California Press. 2002.

BUTLER, C.S.

Diagnosis and treatment of yaws. International Clinics, v.2, 14p. 1930.

BUTLER, C.S.

The medical needs of the Republic of Haiti at the present time. Port-au-Prince: Service d'Hygiène Publique. 1926.

BUTLER, C.S.; PETERSON, E.

The Public Health Service of Haiti: its origin, organisation and present system of administration. Rockefeller Foundation Records, 1. 1. 320. RG 1.1. (Rockefeller Archive Center). 5 Oct. 1926.

CUETO, Marcos.

Visions of science and development: the Rockefeller Foundation's Latin American surveys of the 1920s. In: Cueto, Marcos. Missionaries of science: the Rockefeller Foundation and Latin America. Bloomington: Indiana University Press. 1994.

CUETO, Marcos; PALMER, Steven.

Medicine and public health in Latin America: a history. Cambridge: Cambridge University Press. 2015.

ČEJKOVÁ, Darina et al.

Whole genome sequences of three Treponema pallidum ssp. Pertenue strains: yaws and syphilis treponemes differ in less than $0.2 \%$ of the genome sequence. PLoS Neglected Tropical Diseases, v.6, n.1, e1471. 2012.

DASH, J. Michael.

Haiti and the United States: national stereotypes and the literary imagination. Basingstoke: Palgrave MacMillan. 1997.

ESPINOSA, Mariola.

Epidemic invasions: yellow fever and the limits of Cuban independence. London: The University of Chicago Press. 2009.
FORBES, Cameron.

Hoover adopts plan to get out of Haiti.

H-134.13.14.RG 127. (United States National Archives Building, Washington DC). 28 Mar. 1930.

FOX, Howard.

Yaws (Frambesia Tropica) as observed in Haiti. Archives of Dermitology and Syphilology, v.20, n.6, p.820-834. 1929.

GARDE...

Garde d'Haïti. Annual report: period of Oct. 1. 1933 to July 31. 1934. (Port-au-Prince: Garde d'Haiti. 1934.

GARDE...

Garde d'Haïti. Annual report: period of Oct. 11932 to Oct. 1 1933. Port-au-Prince: Garde d'Haïti. 1933.

GARDE...

Garde d'Haïti. Annual report: period of Oct.

11931 to Oct. 1 1932. Port-au-Prince: Garde d'Haïti. 1932.

GARDE..

Garde d'Haïti. Annual report: period of Oct. 11930 to Oct. 1 1931. Port-au-Prince: Garde d'Haïti. 1931.

GARDE...

Garde d'Haïti. Annual report: period of Oct. 11929 to Oct. 1 1930. Port-au-Prince: Garde d'Haïti. 1930.

GENDARMERIE...

Gendarmerie d' Haïti. Annual report:

Gendarmerie d'Haiti, 1920-1921. H-4.38.10.RG

127. (United States National Archives Building, Washington DC). 15 Jul. 1921.

HOFFMAN, W.A.

Report on mosquito survey in Haiti with special emphasis on the ecological problems which are important in malaria control. Rockefeller Foundation Records. 3266. 256. 1.2. RG 5. (Rockefeller Archive Center). 15 Jan. 1926.

HOWARD, Hector $\mathrm{H}$.

Letter to F.F. Russell. Rockefeller Foundation Records. 3226. 256. 1.2. RG 5. (Rockefeller Archive Center). 20 Sep. 1926.

HOWARD, Hector $\mathrm{H}$.

Letter to F.F. Russell. Rockefeller Foundation Records. 3226. 256. 1.2. RG 5. (Rockefeller Archive Center). 28 May 1926.

HOWARD, Hector $\mathrm{H}$.

Letter to F.F. Russell. Rockefeller Foundation Records. 2866. 225. 1.2. RG 5. (Rockefeller Archive Center). 10 March 1925.

HOWARD, Hector $\mathrm{H}$.

Letter to Charles S. Butler. Rockefeller 
Foundation Records. 2452. 191. 1.2. RG 5. (Rockefeller Archive Center). 20 June 1924.

JOHNSTON, Harry Hamilton.

The Negro in the New World. London: Methuen \& co., ltd. 1910.

JONES, James H.

Bad blood: the Tuskegee syphilis experiment. London: Free Press. 1981.

KAKAR, Sanjiv.

Leprosy in British India, 1860-1940: colonial politics and missionary medicine. Medical History, v.40, n.2, p.215-230. 1996.

MATHIS, Maurice S.; WILSON, Paul W. Epidemiology and pathology of yaws: a report based on a study of one thousand four hundred and twenty-three consecutive cases in Haiti. Journal of the American Medical Association, v.94, n.17, p.1289-1292. 1930.

MAY, H.A; GARRISON, P.E.

Preliminary report upon the sanitary and public health conditions in Port au Prince, Haiti, and its environs. Rockefeller Foundation Records. 189.32.2.RG5. (Rockefeller Archive Center). 1 Oct. 1915.

MCBRIDE, David.

Missions for science: U.S. technology and medicine in America's African world. London: Rutgers University Press. 2002.

MEAD, Elwood.

Letter to the Secretary of the Interior. Rockefeller Foundation Records, 1. 1. 320. RG 1.1.

(Rockefeller Archive Center). 13 Sep. 1926.

MOODY, Joseph L.

Monograph: Port au Prince, Republic of Haiti, prepared by Joseph L. Moody, Jr, 1st Lieutenant, US Marine Corps, Intelligence Officer. H-91.5 Haiti - Cities and Towns - Port-au-Prince. 309.11.38.RG 127. (United States National Archives Building, Washington DC). Aug. 1928.

NICHOLLS, David.

From Dessalines to Duvalier: race, colour and national independence in Haiti. New Brunswick: Rutgers University Press. 1996.

PALMER, Steven.

Launching global health: the Caribbean odyssey of the Rockefeller Foundation. Ann Arbor: The University of Michigan Press. 2010.

PARSONS, Robert.

History of Haitian medicine. New York: P.B. Hoeber. 1930.

PAYNE, George C.

Method by which International Health Board might seek to assist Haiti in public health work.
Rockefeller Foundation Records. 3268. 257. 1.2. RG 5. (Rockefeller Archive Center). 4 Feb. 1926.

PAYNE, George C.

Preliminary report of the field work of Haiti survey. Rockefeller Foundation Reports, 12. 190. 32. 320. (Rockefeller Archive Center). 20 Jan. 1926.

PERINE, Peter L. et al.

Handbook of endemic Treponematoses: yaws, endemic syphilis and pinta. Geneva: World Health Organisation. 1984.

PLUMMER, Brenda Gayle.

Haiti and the United States: the psychological moment. London: University of Georgia Press. 1992.

RAMSEY, Kate.

The spirits and the law: Vodou and power in Haiti. London: The University of Chicago Press. 2011.

RENDA, Mary.

Taking Haiti: military occupation and the culture of U.S. imperialism. Chapel Hill: University of North Carolina Press. 2001.

RINALDI, A.

Yaws eradication: facing old problems, raising new hopes. PLoS Neglected Tropical Diseases, v.6, n.11, e1837. 2012.

ROSE, Wickliffe.

Letter to John C. Russell. Rockefeller Foundation Records. 1812. 126. 1.2. RG 5. (Rockefeller Archive Center). 17 May 1922.

RUSSELL, John C.

Letter to the RF International Health Board, Rockefeller Foundation Records, 1812. 126. 1.2. RG 5. (Rockefeller Archive Center). 14 April 1922.

SAMANE, G.E.

Treponematosis eradication, with special reference to yaws eradication in Haiti. Bulletin of the World Health Organisation, v.15, p.906. 1956.

SCHMIDT, Hans.

The United States occupation of Haiti: 1915-1934. New Brunswick: Rutgers University Press. 1971.

SHEPARD, R.L.

Intelligence report: aux cayes. Folder H-16

Haiti - Cities and Towns - Aux Cayes. 11.38.RG 127. (United States National Archives Building, Washington DC). 2 Dec. 1921.

STEPAN, Nancy.

Eradication: ridding the world of diseases forever? London: Reaktion Books. 2011.

STEPAN, Nancy.

Picturing tropical nature. London: Reaktion Books, 2001. 
ST. JOHN, Spenser.

Hayti, or the Black Republic. London: Ballantyne, Hanson and co. 1888.

STITT, E.R.

Foreword. In: Parsons, Robert. History of Haitian medicine. New York: P.B. Hoeber. 1930.

SUTTER, Paul S.

Nature's agents or agents of Empire?

Entomological workers and environmental change during the construction of the Panama Canal. Journal of the History of Science in Society, v.98, n.4, p.724-754. 2007.
TROUILLOT, Michel-Rolph.

Haiti, State against Nation: the origins and legacy of Duvalierism. New York: Monthly Review Press. 1990.

TURNER, Thomas B.

Studies on the relationship between yaws and syphilis. American Journal of Epidemiology, v.25, n.3, p.477-506. 1937.

WHO.

World Health Organisation. Yaws. Available at: http://www.who.int/mediacentre/factsheets/ fs316/en/. Accessed on: 27 Aug. 2016. Undated. 